\title{
Birth of a mud volcano: East Java, 29 May 2006
}

Richard J. Davies, Centre for Research into Earth Energy Systems (CeREES), Department of Earth Sciences, University of Durham, Science Labs, Durham DH1 3LE, UK, richard.davies@ durham.ac.uk; Richard E. Swarbrick, Geopressure Technology Limited, Mountjoy Research Centre, Stockton Road, Durham, DH1 34Z, UK; Robert J. Evans, 3DLab, School of Earth, Ocean and Planetary Sciences, Main Building, Park Place, Cardiff University, Cardiff CF10 3YE, UK; Mads Huuse, Department of Geology and Petroleum Geology, University of Aberdeen, Aberdeen AB24 3UE, UK

\begin{abstract}
On 29 May 2006, an eruption of steam, water, and, subsequently, mud occurred in eastern Java in a location where none had been previously documented. This "pioneer" mud eruption (the first to occur at this site) appears to have been triggered by drilling of overpressured porous and permeable limestones at depths of $\sim 2830 \mathrm{~m}$ below the surface. We propose that the borehole provided a pressure connection between the aquifers in the limestones and overpressured mud in overlying units. As this was not protected by steel casing, the pressure induced hydraulic fracturing, and fractures propagated to the surface, where pore fluid and some entrained sediment started to erupt. Flow rates remain high (7000-150,000 $\mathrm{m}^{3}$ per day) after 173 days of continuous eruption (at the time of this writing), indicating that the aquifer volume is probably significant. A continued jet of fluid, driven by this aquifer pressure, has caused erosion and entrainment of the overpressured mud. As a result, we predict a caldera will form around the main vent with gentle sag-like subsidence of the region covered by the mud flow and surrounding areas. The eruption demonstrates that mud volcanoes can be initiated by fracture propagation through significant thicknesses of overburden and shows that the mud and fluid need not have previously coexisted, but can be "mixed" within unlithified sedimentary strata.
\end{abstract}

\section{INTRODUCTION}

Understanding how Earth recycles elements, compounds, minerals, or even sediment is a major scientific quest, which transcends several disciplines, including chemistry, biology, and earth science. In sedimentary geologic systems, the cycle time can be particularly significant. For instance, the burial of sediment (and pore fluid) to depths in excess of $5 \mathrm{~km}$, and their remobilization and transport back to Earth's surface, can take millions to tens of millions of years (e.g., Kopf et al., 2003). One prerequisite for this long-term recycling process is the development of elevated pore fluid pressure (overpressure). The excess fluid provides the required energy for the breach of seals and for the transport of a fluid-sediment mix back to the surface, where it is redeposited as sediment (e.g., Stewart and
Davies, 2006; Deville et al., 2006). Mud volcano systems are one of the many expressions of this process, and many have been documented globally (Kopf, 2002; Milkov, 2000). Significant eruptive edifices can develop, which are often grossly similar in form to their more intensively studied igneous counterparts (Stewart and Davies, 2006), although substantially smaller. However, many of the fundamental processes involved in the recycling of buried fluid and sediment through mud volcano systems are poorly understood, and studies are still in their infancy. Elementary questions remain; for instance: (a) Do the fluid and mud come from the same beds, or is the fluid transported from deeper levels into mud source beds where mud is entrained? (b) How is the plumbing system that feeds mud and fluid to the surface initiated and sustained? and (c) What is the three-dimensional architecture of the feeder systems and how do they evolve through time?

On 29 May 2006, a mud eruption was observed in the Porong subdistrict of Sidoarjo in eastern Java (Fig. 1). At the time of this writing, the erupted mud pool (a) has a volume of $\sim 0.012$ $\mathrm{km}^{3}$, (b) covers an area of $\sim 3.6 \mathrm{~km}^{2}$ and is up to $\sim 10 \mathrm{~m}$ thick, (c) has buried 4 villages and 25 factories, and (d) displaced 11,000 people. There have been 13 fatalities as a result of the rupture of a natural gas pipeline that lay underneath one of the holding dams built to retain the mud. The eruption has unofficially been named "Lusi" (Lumpur "mud" Sidoarjo), and this name is adopted here. It occurred during the drilling of a nearby exploration borehole (Banjar Panji-1); therefore, in this case several factors (e.g., pressure, depth, stratigraphy) that are normally not constrained in natural mud volcano systems are calibrated. Although we propose that Lusi is man-made, it does offer a unique opportunity to address the mechanisms of initiation and maintenance of a mud volcano. The aims of this paper are to consider why the eruption occurred, compare it to other natural examples, and evaluate what we can learn about how mud volcano systems work.

\section{MUD VOLCANO SYSTEMS}

Mud volcanoes are common on Earth (Milkov, 2000), but particularly so in compressional tectonic belts (e.g., Azerbaijan:

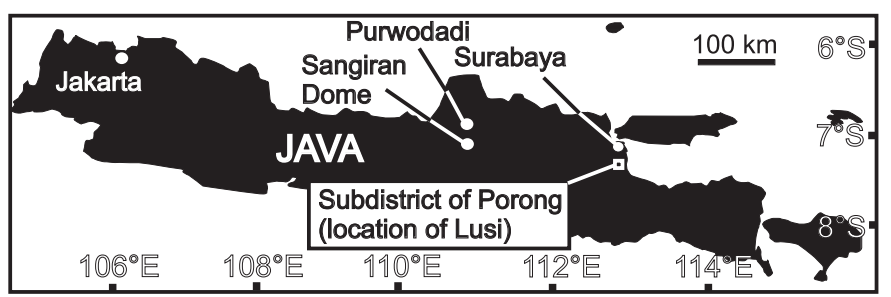

Figure 1. Map of Java, showing the location of the eruption in the Porong subdistrict and Purwodadi and Sangiran Dome, where other mud volcanoes have been documented. 
Planke et al., 2003; Indonesia: Ware and Ichram, 1997), within deltas (e.g., Mississippi: Neurauter and Bryant, 1990), and submarine slopes undergoing gravitationally driven detachment (e.g., Niger delta: Graue, 2000). The volcanoes can be longlived features, composed of a series of mud "cones," which indicate a pulsed eruptive history (Evans et al., 2007) that can occur over $10^{4}-10^{6} \mathrm{yr}$ time spans.

The term "mud volcano system" was coined by Stewart and Davies (2006) to describe the set of structures associated with a constructional edifice (mud volcano) and feeder complex that connects the volcano to its source stratigraphic unit (Fig. 2A). The system is driven by pressure and a source of fluid, which may or may not coexist with mud source beds (see Deville et al., 2003). Above the fluid source is a feeder conduit (Fig. 2B), the detailed structure of which is largely unknown. It probably consists of a complex system of fractures and mud-filled dykes (Fig. 2C) that feed a fluid-sediment mix to Earth's surface (e.g., Morley, 2003). The fluid-sediment mix then erupts to form the "mud volcano" - a term we only use to describe the edifice (Fig. 2D).

The plumbing of mud volcano systems is poorly constrained. For instance, the mud and fluid could coexist at the time of initiation, analogous to magma (e.g., Davies and Stewart, 2005), or the fluid could be transported from a deeper source, remobilizing mud at shallower stratigraphic levels (Deville et al., 2003; Kopf et al., 2003; You et al., 2004). Some mud volcano systems are thought to comprise multiple mud chambers at different stratigraphic levels (Deville et al., 2003; Planke et al., 2003) whereas other models propose that mud volcano systems comprise significant masses of mud, in the form of bulbous-shaped diapirs (Brown, 1990; Milkov, 2000).
A "pioneer mud volcano" (e.g., Fig. 2A) is a term used by Davies and Stewart (2005) to describe the first mud volcano that erupts in a location where no mud volcano system previously existed. They envisage that if a substantial mud volcano develops, a positive feedback loop can become established where subsidence of the overburden due to loading, conduit wall-rock erosion, and volume loss at depth causes new fractures and faults to form in the overburden stratigraphy. These structural apertures provide new pathways for a fluid-mud mix.

\section{GEOLOGIC SETTING}

The East Java basin is an inverted extensional basin (Matthews and Bransden, 1995). It comprises a series of east-weststriking half-graben that were active in extension during the Paleogene and reactivated in compression during the early Miocene to Recent. The Oligo-Miocene to Recent basin was filled with shallow marine carbonates and marine muds, some of which are known to be "overpressured" (see Osborne and Swarbrick, 1997). As a result of the compressional inversion, these strata are gently folded with normal and reverse faults cutting the inversion anticline crests (see Matthews and Bransden, 1995). A small section of one of these east-west-trending anticlines was targeted by the Banjar Panji-1 exploration well.

Mud volcanoes have been documented before in East Java. For example, they are found within the crest of the Sangiran Dome (part of one of the east-west-trending Neogene folds: Watanabe and Kadar, 1985) and near Purwodadi, which is 200 $\mathrm{km}$ west of Lusi (Fig. 1). Overpressured lower Miocene clays probably equivalent to the Tuban or Tawun Formations (similar age to the Kujung limestone-see Matthews and Bransden,

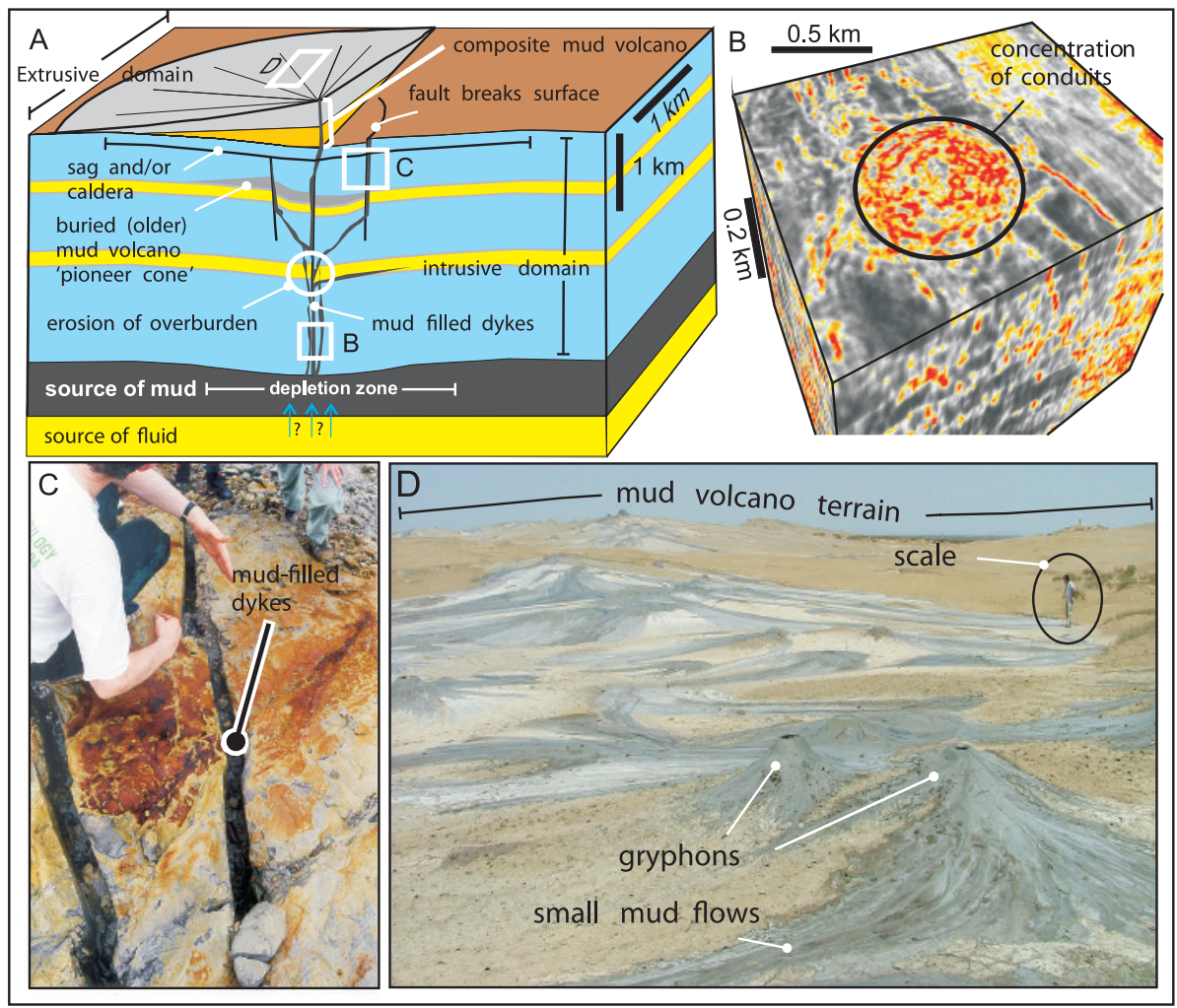

Figure 2. Components of a mud volcano system revealed by three-dimensional seismic data and outcrop. (A) Schematic illustration of the main components of a mud volcano system. Mud volcano systems can be divided into intrusive and extrusive structural domains. Fluid may either coexist with the mud source or enter from a deeper source (blue arrows) causing remobilization of shallower mud and entrainment of other overburden lithologies. The mud-fluid mix is transported through fractures and faults to the surface, where stacked cones form due to episodic eruptive and quiescent periods. (B) Seismic coherency cube (see Bahorich and Farmer, 1995) across the Gunashli mud volcano (South Caspian Sea, from Davies and Stewart, 2005), showing feeder conduits, the detailed internal structure of which is unknown. (C) Mud-filled dykes from the Jerudong anticline in Brunei (see Morley, 2003). These types of mud-filled fractures are potentially what allow for the transport of the mud-fluid mix to the surface. (D) Photograph of mud volcano terrain from Azerbaijan comprising several gryphons from which small mud flows emanate. 
1995) and the Upper Kalibeng Formation are considered to be the source of the mud (Watanabe and Kadar, 1985).

\section{OBSERVATIONS}

\section{Volumes, Rates, and Dimensions}

The typical eruption volume, duration, rate, spatial extent, and aspect ratio of selected naturally occurring mud volcanoes can be compared to Lusi (Tables 1 and 2, respectively). These comparisons show that the Lusi eruption has a significant volume, duration, and spatial extent. The average eruption rate is not particularly high. Lusi has an anomalously high aspect ratio (Table 2). It is also worth noting that long-lived mud volcanoes that consist of several cones that develop as a result of multiple eruptive and non-eruptive developmental stages (Evans et al., 2007) are known to have volumes of up to $\sim 22.5 \mathrm{~km}^{3}$ — dwarfing the current but still highly active Lusi edifice (Stewart and Davies, 2006).

\section{Key Events and Subsurface Data}

Banjar Panji-1 was an exploration well that was targeting gas within Oligo-Miocene age Kujung Formation carbonates within the East Java Basin. The well reached a depth of $2834 \mathrm{~m}$, after which an eruption of steam, water, and a minor amount of gas was observed at 5:00 a.m. on 29 May 2006, 200 m southwest of the well. On the second and third of June 2006, two further eruptions started $800-1000 \mathrm{~m}$ to the northeast of the well, but both of these stopped on 5 June 2006 (United Nations Final Technical Report, 2006). It is reported by local villagers that the water-mud mix at the surface had a temperature of $70-100{ }^{\circ} \mathrm{C}$; a continuous plume of steam seen on early to recent photographs of the eruption supports such high temperatures. An earthquake of magnitude 6.3 occurred at 5:54 a.m. local time on 27 May 2006, with an epicenter $280 \mathrm{~km}$ west-southwest of the Lusi eruption, near Yogyakarta (U.S. Geological Survey, 2006). The eruption of a dilute mud-water mix has persisted from the site of the initial eruption, and mud now covers an area of $\sim 3.6 \mathrm{~km}^{2}$ (Fig. 3).

Unreleased geologic data (lithological log, biostratigraphic determinations, gamma ray, sonic, density logs) indicate that the well drilled the following (shallowest first): (a) the Pleistocene age Pucangan and Kabuh Formations, (b) then $\sim 1000 \mathrm{~m}$ of overpressured muds with some sand interbeds (the Upper Kalibeng Formation [Pleistocene age]), (c) $\sim 1300 \mathrm{~m}$ of interbedded sands and muds, and finally (d) the well penetrated a limestone (presumed to be the Kujung Formation), which was also overpressured. There was no casing set between the bottom of the hole (the Kujung Formation) and $\sim 1743 \mathrm{~m}$ of the overburden, including part of the $1000 \mathrm{~m}$ of overpressured Upper Kalibeng Formation mud and the entire $1300 \mathrm{~m}$ of interbedded muds and sands (Fig. 4A). We know that (a) in the Banjar Panji-1, the pore pressures at $2130 \mathrm{~m}$ (700 $\mathrm{m}$ above the Kujung limestone) are $38 \mathrm{MPa}$ (5500 psi); and (b) that in a well $5 \mathrm{~km}$ away called Porong-1, the pressure within the Kujung limestone aquifer was $48 \mathrm{MPa}(6970 \mathrm{psi})$ at $2597 \mathrm{~m}$.

\section{VOLCANO INITIATION}

\section{Model}

Given the pore pressure of $38 \mathrm{MPa}$ ( $5500 \mathrm{psi}$ ) at $2130 \mathrm{~m}$ in the Banjar Panji-1 well, we calculate an overpressure of $16 \mathrm{MPa}$ (2300 psi) at this depth. In the Porong-1 well, we use the pressure of $48 \mathrm{MPa}$ (6970 psi) at $2597 \mathrm{~m}$ to calculate an overpressure of $21 \mathrm{MPa}$ within the Kujung limestone. On the assumption that the Kujung limestone is a regional aquifer (which seems likely given the high continuous flow rates at Lusi), we predict the overpressure was $\sim 21 \mathrm{MPa}$ at the base of the Banjar Panji-1 at $2830 \mathrm{~m}$.

We propose that the drilling of the overpressured Kujung limestone caused an influx of pore fluid into the well bore (known as a "kick"). The well bore itself provided the pressure connection from the limestone to any shallower aquifers as well as the overpressured muds of the Upper Kalibeng Formation. The eruption started with steam and water, and this did not come to the surface through the well bore, but instead took place 200-1000 $\mathrm{m}$ away (Fig. 4B). Therefore, the transport route for the steam and mud was not through the wellbore but through the surrounding overburden. High pore-pressure causes natural hydraulic fracturing of the sedimentary overburden (see Engelder, 1993) when pore pressures exceed the

TABLE 1. VOLUME, DURATION, AERIAL COVERAGE, AND RATES OF SELECTED LARGE-SCALE MODERN ERUPTIONS FROM THE SOUTH CASPIAN SEA AND TRINIDAD COMPARED TO LUSI*

\begin{tabular}{lcccc}
\hline \hline & $\begin{array}{c}\text { Lokbatan } \\
(\text { Azerbaijan, 2001) }\end{array}$ & $\begin{array}{c}\text { Koturdag (Azerbaijan, } \\
1950 \text {-present) }\end{array}$ & $\begin{array}{c}\text { Piparo } \\
\text { (Trinidad, 2001) }\end{array}$ & $\begin{array}{c}\text { Lusi } \\
\text { (East Java, 2006) }\end{array}$ \\
\hline Volume & $0.0003 \mathrm{~km}^{3}$ & $0.00045 \mathrm{~km}^{3}$ & $0.025 \mathrm{~km}^{3}$ & $0.012 \mathrm{~km}^{3}$ \\
Duration & 30 minutes & 18,200 days & 1 day & 173 days \\
Area & $0.098 \mathrm{~km}^{2}$ & $0.3 \mathrm{~km}^{2}$ & $2.5 \mathrm{~km}^{2}$ & $3.6 \mathrm{~km}^{2}$ \\
Average rate $^{\dagger}$ & 0.0144 & 0.000000025 & 0.025 & $0.00007-0.0015$ \\
\hline
\end{tabular}

*The duration of the Lusi eruption is at the time of this writing.

${ }^{\dagger} \mathrm{km}^{3}$ per day.

TABLE 2. ASPECT RATIOS* FOR MUD VOLCANOES FROM THE SOUTH CASPIAN SEA AND LUSI

\begin{tabular}{|c|c|c|c|c|c|}
\hline & $\begin{array}{c}\text { Gunashli (South } \\
\text { Caspian Sea) }\end{array}$ & $\begin{array}{c}\text { Lokbatan } \\
\text { (Azerbaijan) }\end{array}$ & $\begin{array}{c}\text { Sangachal } \\
\text { (Azerbaijan) }\end{array}$ & $\begin{array}{l}\text { Chirag (South } \\
\text { Caspian Sea) }\end{array}$ & Lusi \\
\hline Aspect ratio & $16: 1$ & $30: 1$ & $14: 1$ & $40: 1$ & $250: 1$ \\
\hline
\end{tabular}




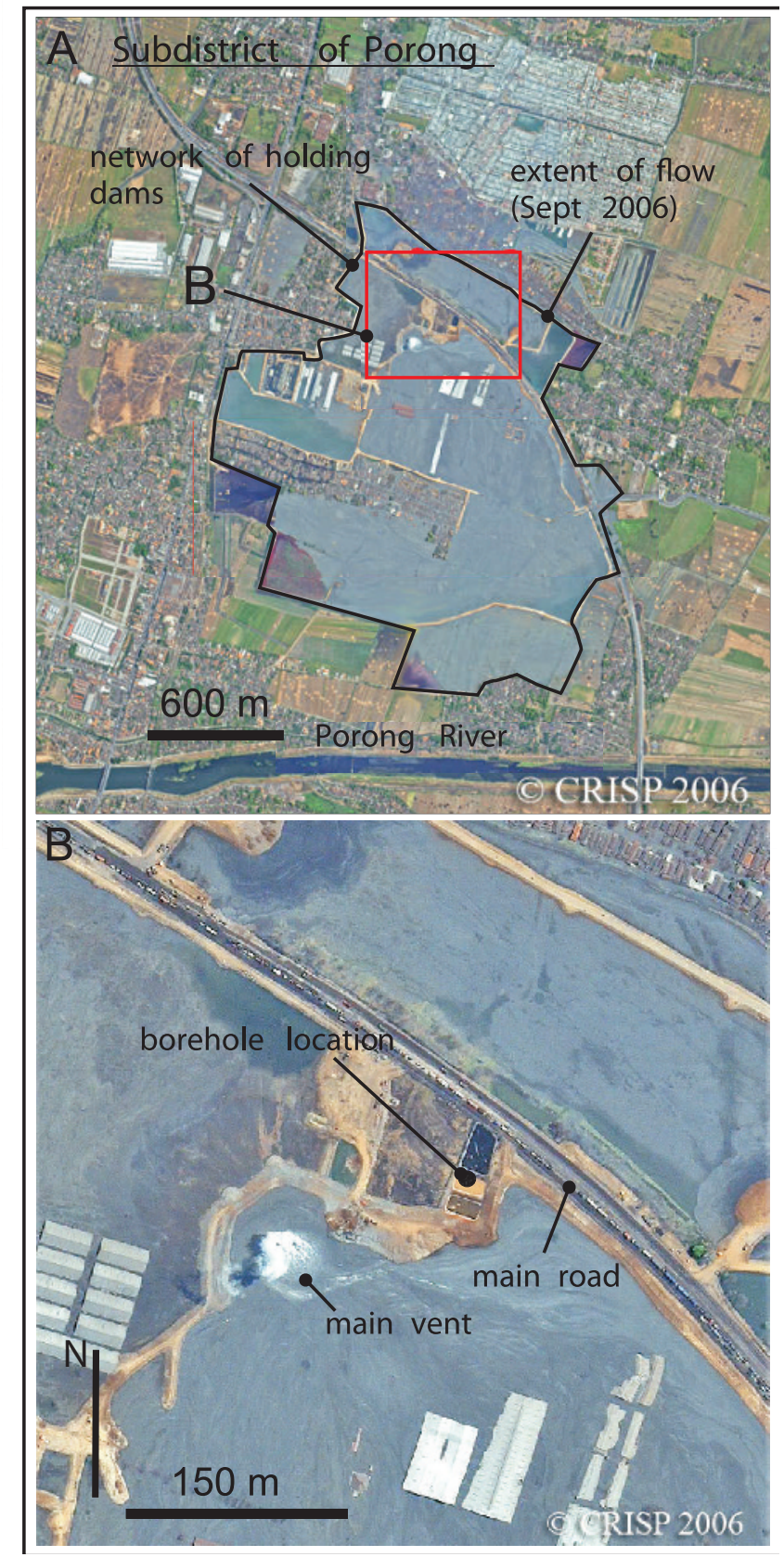

Figure 3. Satellite images of the Lusi eruption taken 100 days after the eruption started. (A) Entire area of eruption. (B) Close-up of the main vent (marked by clouds of steam [white]), which appeared $200 \mathrm{~m}$ southwest of the exploration well. Both images taken September 2006, courtesy National University of Singapore Centre for Remote Imaging, Sensing and Processing (CRISP).

fracture strength. These conditions for the creation of hydraulic fractures are most likely to form in the shallowest strata not protected by steel casing. We propose that the fractures probably formed within the Upper Kalibeng Formation and propagated from $1-2 \mathrm{~km}$ depth to the surface over a period of hours. The depth is backed by the temperature of the erupted mud-water mix, which is $70-100{ }^{\circ} \mathrm{C}$, indicative of rapid transport from 1.5 to $3 \mathrm{~km}$ depth, assuming a geothermal gradient of $25^{\circ} \mathrm{C} / \mathrm{km}$ and a surface temperature of $28^{\circ} \mathrm{C}$. Such drilling-induced fracture and fluid flow processes, where the well bore provides the

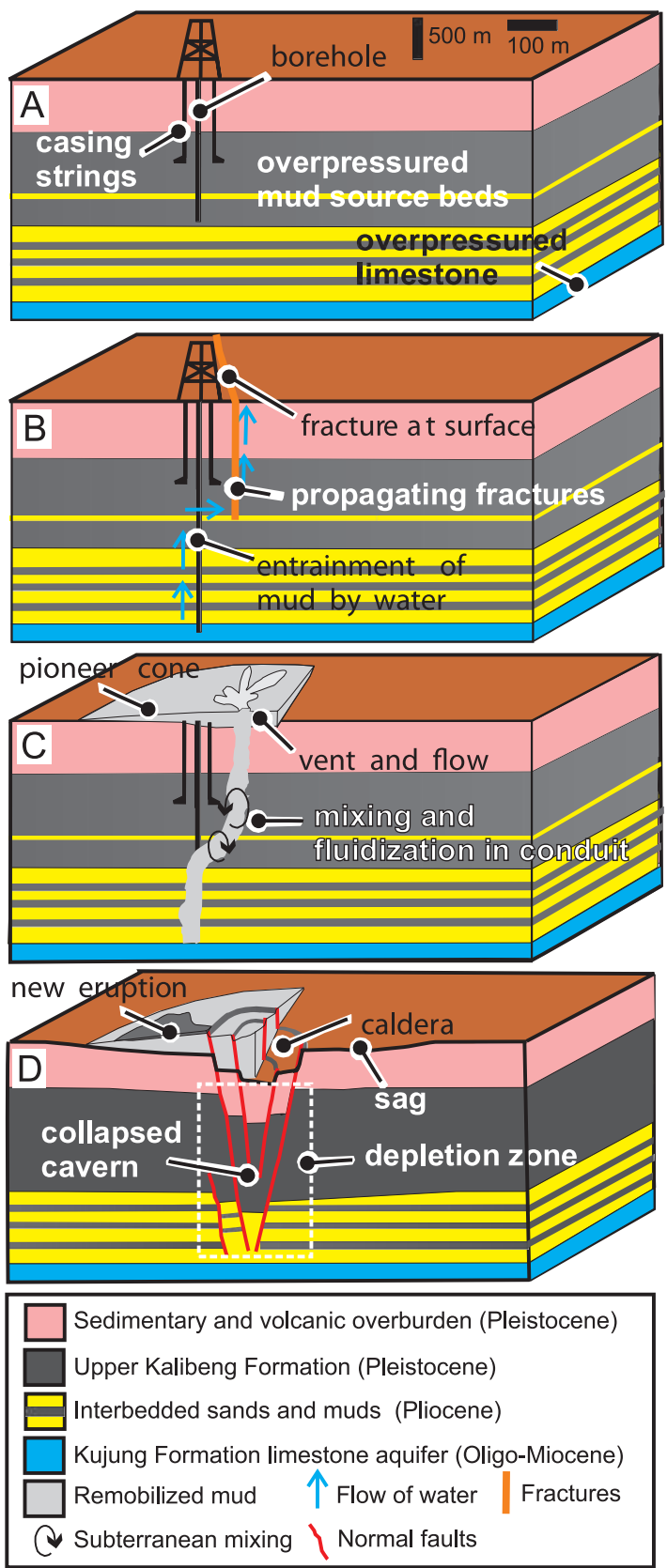

Figure 4. Schematic three-dimensional representations of the Lusi mud volcano showing four main developmental stages. The first three diagrams depict the evolution between May 2006 and Dec. 2006 (A-C), and the fourth diagram (D) shows the predicted next phase of evolution. (A) March to May 2006: Banjar Panji-1 well drills toward Kujung Formation, through overpressured mud (Kalibeng Formation) and interbedded sands and muds. (B) May 2006: Kujung Formation carbonates are penetrated, which leads to a "kick" (influx of fluid into the well bore). The kick causes hydrofracturing of overlying strata (probably initiated within the Kalibeng Formation). Drilling mud and pore-fluid enter the well bore, driven by the excess pressure upward, through porous and permeable strata and the fracture system. Entrainment of overpressured Kalibeng Formation muds occurred. (C) May to December 2006: entrainment of Kalibeng Formation muds causes a subterranean conduit to form, the walls of which undergo period collapse. (D) Post-2006: caldera forms around the vent, and gentle sag-like subsidence of the region where the flow extends. Smaller mud cones may be erupted as a result of conduit establishment due to foundering of the overburden stratigraphy. 
necessary initial pressure communication, has been witnessed elsewhere; for example, in subsurface blowouts that occurred in Brunei in 1974 and 1979 (see Tingay et al., 2005).

At Lusi, the influx of pore water into the well bore may have initially come from the Kujung limestones, but once the heavy drilling mud had been displaced into the new fractures, fluid would have also started to flow from porous and permeable formations in the overburden. The passage of fluid into overpressured (and therefore undercompacted) mud would lead to entrainment of the unlithified sediment (Fig. 4C), which would also contribute its pore water to the mix. Mud is cohesive, and in a similar way to the entrainment of mud in sedimentary settings, the shear stress imposed by the adjacent moving water has to overcome the sediment's cohesive yield strength (e.g., Dade et al., 1992; Kranenburg and Winterwerp, 1997) for it to be entrained. Such an entrainment process has been proposed for mud volcanoes in the UK, for instance, where water from an underlying aquifer passes through mud-rich overburden, causing the formation of a subterranean cavern system (Bristow et al., 2000). The same general process has also been proposed by Deville et al. (2003) for mud volcanoes in Trinidad. We envisage that collapse of the Upper Kalibeng strata will contribute to the mixing process. It is also conceivable that the hot water in large caverns will allow convection cells to develop, which will contribute to the mixing process (e.g., Deville et al., 2003). The resultant dilute water-mud mix is moving up fractures to the surface as a fluidized sediment flow with the mud in suspension.

The mix started to erupt at the surface, driven by the pressure of the pore fluids in the Kujung limestones. Erosion of the walls of the fractures is also likely (it occurs in other mud volcanoes), and therefore a major conduit would grow upward and laterally, periodically collapsing inward. This particular mixing mechanism for mud volcanism has probably led to the very dilute composition of the mud-water mix and the high aspect ratio of the edifice.

\section{Pressure Drive}

If a continuous $2830 \mathrm{~m}$ column of an erupting mud-water mix has a density of $1.3 \mathrm{gcm}^{-3}$, based on an assumed water: mud ratio of $80: 20$, the mud column would exert a pressure of $36 \mathrm{MPa}$ ( $5225 \mathrm{psi}$ ) at the bottom of the Banjar Panji-1 exploration hole. This pressure is $12 \mathrm{MPa}$ less than our estimate of the pressure within the Kujung limestone (48 MPa); therefore, it is most likely that the flow that is being witnessed is driven by this pressure difference. Gas exsolution and expansion (Brown, 1990) are not considered important lift mechanisms at present.

\section{NEXT DEVELOPMENTAL STAGES}

Maintenance of flow depends upon one of two factors. If there is a continuous pathway to the surface due to the subsurface erosion of the conduit walls, the influx of the pore fluid and eruption will continue until the aquifer pressure equals the pressure due to the vertical column of erupting mud-water mix (i.e., $12 \mathrm{MPa}$ ). Alternatively, if mud gains access to the surface through fractures that remain open against the minimum stress, flow will reduce substantially only when the fracture closure pressure is reached; this pressure will depend on the depth at which the fracture(s) occur. Once the pressure drive abates, the compaction of the extruded and intruded mud can cause low levels of mud-water eruption, potentially for years or decades to come, as noted in other mud volcanoes such as Piparo in Trinidad and many mud volcanoes in Azerbaijan between violent (active) eruptive phases.

If our model of entrainment of the mud within the Upper Kalibeng Formation is correct, then unless the pore pressure drops to allow flow to stop, the subterranean caverns will undergo collapse (Fig. 4D). We predict that the region around the vent will form a caldera and that the area of the mud flow will undergo less significant sag-like subsidence. This subsidence pattern is consistent with the behavior of other mud volcanoes (Stewart and Davies, 2006). The subsidence that caused the fracture of a gas pipeline buried by the mud volcano and dam system indicates that collapse may have already started.

\section{DISCUSSION}

\section{Induced by Drilling or Earthquake?}

We propose that Lusi is the direct result of connection of a high-pressure fluid at depth with shallow sediments at a depth at which fractures can be initiated. Once initiated, the fractures would have propagated to the surface, driven by the deep pressure. Drilling activity has allowed this connection, and our preferred model is that the earthquake that occurred two days earlier is coincidental. The primary reasons for not considering an earthquake to be the trigger or contributing factor are (a) no other mud volcano eruptions were reported in Java at the same time; (b) the earthquake preceded the eruption by two days; seismogenic liquefaction usually occurs during earthquake-induced shaking of sediment (e.g., Ambraseys, 1988); (c) there are no reports of a "kick" during the earthquake or immediately afterward; and (d) sand, rather than mud, is more conducive to liquefaction due to earthquake shaking because it is a non-cohesive, granular sediment. An earthquake could have generated new fractures and weakened the uncased section of the well, but it would be highly coincidental for an earthquake-induced fracture to form $200 \mathrm{~m}$ away from this well and provide the entire fracture network required for an eruption on the Earth's surface.

\section{Initiation and Subterranean Mixing}

A fundamental question in mud volcano system studies is how they are initiated. The model proposed by Brown (1990), Van Rensbergen et al. (1999), Davies and Stewart (2005), and Stewart and Davies (2006) is that hydrofractures can penetrate several kilometers of the crust and transport a fluid-sediment mix that erupts to form a pioneer volcano. Because in this case we know that the mud-water mix has been transported $\sim 2 \mathrm{~km}$ through the overburden, through new or reactivated fractures, the Lusi eruption supports the models proposed by these authors.

The Lusi eruption also strengthens the concept that rather than the source water and the source mud coexisting in the same stratigraphic unit (mudrocks at $2.0 \mathrm{~km}$ depth have strength and not the porosity of $70 \%-80 \%$ required for the Lusi sediment composition), the fluid has a deeper source, and mud is entrained from within the overburden (e.g., Bristow et al., 
2000; Deville et al., 2003; Kopf et al., 2003; You et al., 2004). This subterranean mixing model differs from the concept of mud and fluid coexisting (Davies and Stewart, 2005; Stewart and Davies, 2006) and contrasts with models for the subsurface remobilization of sands where coexistence of sand and fluid is the general assumption. The mud is particularly susceptible to entrainment due to overpressure, which does not allow normal compaction (Osborne and Swarbrick, 1997). The aquifer pressure provides the pressure drive.

\section{Common Phenomena?}

Subsurface blowouts are not uncommon events (e.g., Tingay et al., 2005) and can involve sediment entrainment, but this scale of sediment mobilization, triggered by drilling activity, has not been documented before. A combination of factors account for this being so rare: (1) the penetration of an overpressured mud that is susceptible to erosion followed by (2) the penetration of an aquifer that releases large volumes of pore water and (3) the man-made pressure linkage provided by $1.7 \mathrm{~km}$ of open hole section.

\section{CONCLUSIONS}

It is very likely that Lusi was initiated as a result of access by a high-pressure aquifer at depths in the region of 2.5-2.8 $\mathrm{km}$ through an open-hole section of the Bajar Panji-1 well to depths at which fractures could be initiated. Lusi indicates that mud volcanoes can be initiated by fracture propagation from multi-kilometer depths, which triggers fluid flow and the rapid establishment of a subterranean mixing system, into which water is transported from deeper successions.

Prediction of the next developmental stages is fraught with difficulty, but the unabated 173 days of very active eruption indicate a large aquifer has been penetrated, and we can be confident that some sort of eruptive activity (perhaps lower-level) will continue for many months and possibly years to come. A region several kilometers wide should undergo sag-like subsidence over the coming months with more dramatic collapse surrounding the main vent. Modeling and direct measurement of the inevitable land subsidence will help to predict what the future impact the Lusi mud volcano has on the local population.

\section{ACKNOWLEDGMENTS}

R. Davies is grateful to Anthony Mallon for discussion. Mark Tingay is thanked for the photograph in Figure 2C. We are extremely grateful to the National University of Singapore Centre for Remote Imaging, Sensing and Processing (CRISP) for permission to use the satellite images. We thank Achim Kopf, Peter Van Rensbergen, and an anonymous reviewer for thoughtful and prompt reviews and Gerry Ross for guidance during the preparation of this paper.

\section{REFERENCES CITED}

Ambraseys, N.N., 1988, Engineering seismology: Earthquake Engineering and Structural Dynamics, v. 17, p. 1-105

Bahorich, M., and Farmer, S., 1995, 3-D seismic discontinuity for faults and stratigraphic features: The coherence cube: The Leading Edge, v. 14, p. 1053-1058, doi: 10.1190/1.1437077

Bristow, C.R., Gale, I.N., Fellman, E., and Cox, B.M., with Wilkinson, I.P. and Riding, J.B., 2000, The lithostratigraphy, biostratigraphy and hydrogeological significance of the mud springs at Templars Firs, Wootton Bassett, Wiltshire: Proceedings of the Geologist's Association, v. 111, p. 231-245.

Brown, K.M., 1990, The nature and hydrogeological significance of mud diapirs and diatremes for accretionary prisms: Journal of Geophysical Research, v. 95 p. 8969-8982.
Dade, W.B., Nowell, R.M., and Jumars, P.A., 1992, Predicting erosion resistance of muds: Marine Geology, v. 105, p. 285-297, doi: 10.1016/00253227(92)90194-M.

Davies, R.J., and Stewart, S.A., 2005, Emplacement of giant mud volcanoes in the South Caspian Basin: 3D seismic reflection imaging of their root zones: Journal of the Geological Society [London], v. 162, p. 1-4, doi: 10.1144/0016764904-082.

Deville, E., Battani, A, Griboulard, R., Guerlais, S, Herbin, J.P., Houzay, J.P., Muller, C., and Prinzhofer, A., 2003, The origin and processes of mud volcanism: New insights from Trinidad, in Van Rensbergen, P., Hillis, R.R., Maltman, A.J., and Morley, C.K, eds., Subsurface Sediment Mobilization: London, Geological Society Special Publication 216, p. 475-490.

Deville, E., Guerlais, S.-H., Callec, Y., Griboulard, R., Huyghe, P., Lallemant, S., Mascle, A., Noble, M., and Schmitz, J., 2006, Liquefied vs stratified sediment mobilization processes: Insight from the South of the Barbados accretionary prism: Tectonophysics, v. 428, p. 33-47, doi: 10.1016/j.tecto.2006.08.011.

Engelder, T., 1993, Stress Regimes in the Lithosphere: Princeton, New Jersey, Princeton University Press, $457 \mathrm{p}$.

Evans, R.J., Davies, R.J., and Stewart, S.A., 2007, Internal structure and eruptive history of a kilometre-scale mud volcano system, South Caspian Sea: Basin Research (in press).

Graue, K., 2000, Mud volcanoes in deepwater Nigeria: Marine and Petroleum Geology, v. 17, p. 959-974, doi: 10.1016/S0264-8172(00)00016-7.

Kopf, A.J., 2002, Significance of mud volcanism: Reviews of Geophysics, v. 40, $52 \mathrm{p}$.

Kopf, A., Deyhle, A., Lavrushin, V.Y., Polyak, B.G., Gieskes, J.M., Buachidze, G.I., Wallmann, K., and Eisenhauer, A., 2003, Isotopic evidence (He, B, C) for deep fluid and mud mobilization from mud volcanoes in the Caucasus continental collision zone: International Journal of Earth Sciences, v. 92, p. 407-425.

Kranenburg, C., and Winterwerp, J.C., 1997, Erosion of fluid mud layers: 1: Entrainment model: Journal of Hydraulic Engineering, v. 123, p. 504-511, doi: 10.1061/(ASCE)0733-9429(1997)123:6(504).

Matthews, S.J., and Bransden, P.J.E., 1995, Late Cretaceous and Cenozoic tectonostratigraphic development of the East Java Sea Basin, Indonesia: Marine and Petroleum Geology, v. 12, p. 499-510, doi: 10.1016/0264-8172(95)91505-J.

Milkov, A.V., 2000, Worldwide distribution of submarine mud volcanoes and associated gas hydrates: Marine Geology, v. 167, p. 29-42, doi: 10.1016/S00253227(00)00022-0.

Morley, C.K., 2003, Outcrop examples of mudstone intrusions from the Jerudong anticline, Brunei Darussalam and inferences for hydrocarbon reservoirs, in Van Rensbergen, P., Hillis, R.R., Maltman, A.J., and Morley C.K., eds., Subsurface Sediment Mobilization: London, Geological Society Special Publication 216, p. 381-394.

Neurauter, T.W., and Bryant, W.R., 1990, Seismic expression of sedimentary volcanism on the continental slope, northern Gulf of Mexico: Geo-Marine Letters, v. 10, p. 225-231, doi: 10.1007/BF02431069.

Osborne, M.J., and Swarbrick, R.E., 1997, Mechanisms for generating overpressure in sedimentary basins: A reevaluation: AAPG Bulletin, v. 81, p. 1023-1041.

Planke, S., Svensen, H., Hovland, M., Banks, D.A., and Jamtveit, B., 2003, Mud and fluid migration in active mud volcanoes in Azerbaijan: Geo-Marine Letters, v. 23, p. 258-268, doi: 10.1007/s00367-003-0152-z.

Stewart, S.A., and Davies, R.J., 2006, Structure and emplacement of mud volcano systems in the South Caspian Basin: AAPG Bulletin, v. 90, p. 753-770.

Tingay, M.R.P., Hillis, R.R., Morley, C.K., Swarbrick, R.E., and Drake, S.J., 2005, Present-day stress orientation in Brunei: A snapshot of 'prograding tectonics' in the Tertiary delta: Journal of the Geological Society [London], v. 162, p. 39-49, doi: 10.1144/0016-764904-017.

United Nations Final Technical Report, 2006, United Nations Disaster Assessment and Coordination mission in June \& July 2006 and follow-up mission in July 2006: Published in Switzerland by the Joint UNEP/OCHA Environment Unit, 53 p., http://rovicky.wordpress.com/files/2006/09/environment_assessment_ report_final.pdf.

U.S. Geological Survey, 2006, http://earthquake.usgs.gov/eqcenter/eqinthenews/ 2006/usneb6/.

Van Rensbergen, P., Morley, C.K., Ang D.W Hoan, TQ, and Lam, N.T., 1999 Structural evolution of shale diapirs from reactive rise to mud volcanism: 3D seismic data from the Baram delta, offshore Brunei Darussalam: Journal of the Geological Society [London], v. 156, p. 633-650.

Ware, P., and Ichram, L.O., 1997, The role of mud volcanoes in petroleum systems: Examples from Timor, the south Caspian, and the Carribean, in Howes, J.V.C., and Noble, R.A., eds., Proceedings, IPA Petroleum Systems of SE Asia and Australia Conference, Jakarta, Indonesia: Independent Petroleum Association, p. 955-970.

Watanabe, N., and Kadar, D., 1985, Quaternary geology of the hominid fossil bearing formations in Java, in Watanabe, N., and Kadar, D., eds., Report of the Indonesia-Japan Joint Research Project CTA-41, 1976-1979: Bandung, Indonesia, Geological Research and Development Centre Special Bulletin 4.

You, C.-F., Gieskesb, J.M., Leec, T., Yuic, T.-F., and Chenc, H.-W., 2004, Geochemistry of mud volcano fluids in the Taiwan accretionary prism: Applied Geochemistry, v. 19, p. 695-707, doi: 10.1016/j.apgeochem.2003.10.004.

Manuscript received 1 November 2006; accepted 10 December 2006. 